\title{
STRATEGI DAN PENGENDALIAN KEPEMIMPINAN MADRASAH DALAM MENINGKATKAN MUTU PENDIDIKAN DI MAN 1 YOGYAKARTA
}

\author{
Rohman \\ Sekolah Tinggi Agama Islam Negeri Mandailing Natal \\ Email: rohman@stain-madina.ac.id
}

\begin{abstract}
This study aims to show the application of the strategy and Madrasah leadership management towards quality improvement of education. The location of the study was conducted at Madrasah Aliyah Negeri 1 Yogyakarta (MAN 1 Yogyakarta). This type of research is a qualitative descriptive and data collection method is done by non-participant observation, in-depth interviews, and documentation. The result shown that the head of madrasah had applied strategic steps towards quality improvement of education. The priority in teachers' training to improve their skill and learning process among students in three domains; academic, tahfidz and research. In optimizing these steps madrasah collaborates with education stakeholders, universities, training centers, academics and the community to provide guidance and assistance in improving the learning process in the internal madrasah. Besides the head of the madrasah manage activities by distributing responsibilities to each field in the madrasah organization. In addition, the relationship between the headmaster and its member are built through an intensive dialogical approach and open communication with the aim that works can be carried out together in order to improve the quality of education.
\end{abstract}

Keywords: Strategy, Management, Quality of Education, Madrasah

\begin{abstract}
Abstrak: Penelitian ini bertujuan untuk memperlihatkan penerapan strategi dan pengendalian kepemimpinan Madrasah dalam rangka meningkatkan mutu pendidikan. Lokasi penelitian dilakukan di Madrasah Aliyah Negeri 1 Yogyakarta (MAN 1 Yogyakarta). Jenis penelitian ini adalah deskriptif kualitatif dan metode pengumpulan data dilakukan dengan observasi non partisipan, wawancara mendalam, dan dokumentasi. Hasil penelitian menunjukkan bahwa langkah-langkah strategis yang dilakukan kepala madrasah dalam meningkatkan mutu pendidikan berupa prioritas pada kegiatan pelatihan terhadap guru untuk meningkatkan skil mereka, dan prioritas peningkatan proses pembelajaran di kalangan siswa dalam tiga ranah yaitu akademis, tahfidz, dan riset. Dalam optimalisasi langkah-langkah tersebut pihak madrasah melakukan kerja sama dengan para stakeholders pendidikan, yakni perguruan tinggi, balai pelatihan, akademisi dan masyarakat guna memberi bimbingan dan pendampingan dalam meningkatkan proses pembelajaran di internal madrasah. Sementara pengendalian yang dilakukan kepala madrasah terhadap aktivitas kerja dengan cara mendistribusikan tanggung jawab terhadap masing-masing bidang dalam organisasi madrasah. Di samping itu hubungan kepala madrasah dengan bawahan dibangun dengan pendekatan dialogis dan keterbukaan komunikasi yang intensif dengan tujuan agar aktivitas kerja dapat dilakukan secara bersama-sama dalam rangka meningkatkan mutu pendidikan.
\end{abstract}

Kata Kunci: Strategi, Pengendalian, Kepemimpinan, Mutu Pendidikan, Madrasah.

\section{PENDAHULUAN}

Secara makro, mutu pendidikan Indonesia di tingkat sekolah maupun madrasah masih rendah. Dalam hal prestasi siswa Indonesia masih di bawah siswa Malaysia dan Singapura sebagai Negara tetangga yang terdekat (Musfah, 2015: 52). Laporan Political and Economic Risk Consultant (PERC) menyatakan bahwa kualitas pendidikan di Indonesia berada pada posisi ke-12 dari 12 negara di Asia 
(https://www.unsur.ac.id/berita-907/Ada-Apa-dengan-Pendidikan-di-Indonesia).

Sementara berdasarkan prestasi di bidang sains dan matematika siswa Indonesia juga masih dikatakan rendah. Disebutkan bahwa siswa Indonesia masih mampu mengenali fakta dasar namun belum handal dalam mengkomunikasikan, mengaitkan variasi topik dan mengaplikasikan konsep-konsep yang abstrak dan kompleks dalam matematika dan sains (Hadi dan Novaliyosi, 2019:562).

Laporan di atas menunjukkan bahwa Indonesia masih perlu banyak berbenah dalam hal memperbaiki mutu pendidikan. Alasan kenapa Indonesia masih belum menunjukkan mutu pendidikan yang baik karena pelaksanaan pendidikan di Indonesia masih memiliki banyak kesenjangan baik pada tataran kebijakan, manajemen, anggaran, kurikulum, hingga masalah kesenjangan sumber daya yang dimiliki oleh masing-masing sekolah (lihat: Suryadi, dkk.., 2014:64). Sementara penelitian Zaedun Na'im (2019:275) menyebutkan bahwa untuk memperbaiki mutu pendidikan dapat dilakukan dengan penerapan teknologi pendidikan.

Banyak cara yang dapat dilakukan untuk meningkatkan mutu pendidikan. Dalam perspektif ini mutu pendidikan dapat 'digenjot' dengan pendekatan strategis yang dilakukan pimpinan sekolah/madrasah, sebab kepemimpinan yang baik memberi pengaruh besar untuk membangun mutu dan keprofesionalan kerja di sekolah (Sirojuddin, 2020:119). Kepemimpinan yang tangguh dan mampu mengambil langkahlangkah strategis dilakukan agar proses pembelajaran di sekolah memiliki dimensi mutu yang dapat dinikamti oleh setiap warga sekolah/madrasah. Dengan demikian pimpinan sekolah/madrasah tidak perlu mununggu perubahan dari atas, di balik itu dia harus memberikan inovasi dan tawaran jitu agar sekolahnya dapat terus berjalan menuju mutu yang diharapkan.

Namun jika melihat jenis sekolah pada jenjang atas di Indonesia, madrasah pada akhir-akhir ini telah menunjukkan posisi yang bersaing dan daya tawar (bargaining) yang baik dibanding sekolah umum. Berbagai prestasi dan penghargaan telah banyak diraih oleh madrasah di Indonesia baik dalam bidang sains maupun ilmu sosial lainnya (https://edukasi.kompas.com/read/2019/09/18/16555221/kompetisi-sains-madrasahmembongkar-stigma-sekolahan-kelas-dua). Hal ini menandakan bahwa madrasah tidak dapat dipandang remeh dalam pengelolaan manajemen dan strategi yang dijalankan di dalamnya. Sehingga dapat dikatakan di balik prestasi yang diraih madrasah, di situ terdapat kepemimpinan yang tangguh yang mampu menjalankan strategi dan 
pengendalian dan pendekatan yang baik terhadap bawahan sehingga program pendidikan yang bermutu dapat diwujudkan (Baswedan, 2015: 5).

Berangkat dari uraian di atas, penelitian ini menganalisis secara kritis strategi dan pengendalian kepemimpinan yang dijalankan oleh pimpinan Madrasah Aliyah Negeri 1 Yogyakarta (MAN 1 Yogyakarta). Sebagai madrasah yang unggul di kota Yogyakarta, MAN 1 ini telah menjadi magnet yang mampu menggaet peserta didik yang datang dari berbagai daerah di luar provinsi dengan tawaran proses pembelajaran yang bermutu di madrasahnya. Setali dengan keunggulannya, MAN 1 Yogyakarta telah banyak menorehkan prestasi yang berasal dari para siswa baik di tingkat nasional maupun internasional. Atas dasar itu penelitian ini dilakukan sebagai upaya untuk memperlihatkan bagaimana strategi dan pengendalian yang dilakukan para pimpinan madrasah dalam konteks meningkatkan mutu pendidikan sehingga menjadi madrasah yang unggul. Di samping itu juga sebagai gambaran bagi madrasah atau sekolah lainnya dalam melakukan langkah-langlah strategis dalam mengelola madrasah yang baik dan bermutu.

\section{LANDASAN TEORI}

\section{Strategi dalam Pengelolaan Pendidikan}

Strategi umumnya lebih dikenal dalam dunia usaha ketika menjalankan siasat perusahaan untuk mendapatkan keuntungan (profit) atau keberhasilan. Menurut Robin dalam Imam Machali dan Ara Hidayat (2016:202) strategi merupakan rumusan kerja yang terkonsep, spesifik, jelas dan memiliki kekhususan. Strategi akan memaksimalkan keunggulan kompetitif dan meminimalkan keterbatasan bersaing. Pengertian ini mengisyaratkan bahwa suatu usaha akan tercapai jika dilakukan dengan kajian yang jelas mengenai rencana yang akan dibuat oleh suatu lembaga, dan ada upaya yang berkesinambungan untuk terus meningkatkan kualitas produk yang dihasilkan agar tetap bersaing dengan lambaga lain.

Imam Machali dan Ara Hidayat (2016:12) menuturkan strategi dalam rumusannya adalah serangkaian tindakan yang meliputi perencanaan (planning) pengkoordinasian (organizing), pengimplementasian (actuating), dan pengendalian (controlling) yang dilakukan oleh seluruh komponen organisasi dalam mencapai tujuan. Perumusan strategi meliputi penentuan langkah strategis (strategy formulating) pengimplementasian strategi (strategy implementing) dan pengendalian strategi (strategy evaluating). Strategi dalam 
konteks dapat dimengerti adalah sebagai langkah jitu dari sebuah lembaga dalam mempercepat pencapaian tujuan yang mereka inginkan.

Strategi dalam pengelolaan pendidikan menurut Syaiful Sagala (2013: 128) adalah upaya untuk lebih mengefektifkan pengalokasian sumber daya yang ada dalam pencapaian tujuan pendidikan. Lebih lanjut Sagala menjelaskan, tujuan yang akan dicapai dengan langkah strategik ini adalah dengan memformulasikan poin-poin yang diinginkan dapat tercapai secara menyeluruh dalam satu periode (Sagala, 2013). Seluruh komponen yang ada di sekolah/madrasah kemudian mengartikulasikan hasil-hasil pencapaian dari program sekolah, sehingga visi dan misi terjangkau secara jelas. Pihak lain yang juga berperan penting dalam keberhasilan langkah strategis yang diambil pihak sekolah/madrasah yaitu kekuatan dari luar Lembaga seperti asosiasi guru, stakholders Pendidikan, orang tua siswa, supplier kebutuhan sekolah, pemerintah dan kelompok social yang memberi perhatian langsung pada program sekolah/madrasah.

Berdasarkan penjelasan di atas, penerapan strategi dalam lembaga pendidikan, akan melibatkan banyak pihak dalam menentukan tujuan pendidikan yang ingin dicapai oleh suatu madrasah. Namun dalam pelibatan banyak pihak tersebut terlihat pada perencanaan program-program pendidikan yang hendak dicapai. Di samping itu kepemimipinan yang responsif terhadap keadaan di lingkungan sekolah/madrasah dan masyarakat juga menjadi peranan penting dalam memperkuat strategi yang diterapkan, sebab model kepemimpinan yang tanggap terhadap semua kebutuhan akan mutu dan kualitas pembelajaran di sekolah/madrasah akan menentukan pencapaian strategi yang dijalankan oleh manajemen lembaga pendidikan.

\section{Pengendalian dalam Aktivitas Pendidikan}

Pengendalian secara definitif sebenarnya sering dipertukarkan dengan pengertian pengawasan dan kontrol. Husaini Usman (2014: 534), menjelaskan bahwa pengendalian adalah bagian akhir dari fungsi manajemen. Fungsi manajemen yang menjadi objek pengendalian yaitu planning, organizing, actuating, dan pengendalian atau controlling itu sendiri. Lebih lanjut Usman menjelaskan bahwa pengendalian berdasarkan tahapannya yaitu berupa pemantauan, memberikan penilaian, dan pengumpulan pelaporan atas hasil kegiatan yang telah ditetapkan sehingga menjadi acuan dalam penyempurnaan kegiatan selanjutnya. Pengendali dengan pengawas secara distingtif dapat dijelaskan bahwa pengendali memiliki wewenang turun tangan, sedangkan pengawas hanya sebatas 
memberi saran, sementara tindak lanjutnya dilakukan oleh pengendali (Usman 2014: 534).

Melalui uraian di atas, yang menjadi pokok pengertiannya adalah pada wilayah fungsi dan cara kerja pengendalian. Konsep pengendalian akan melibatkan banyak unsur di dalam sebuah lembaga pendidikan. Jika pimpinan lembaga pendidikan (kepala madrasah) sebagai penanggung jawab pertama dalam proses pengelolaan pendidikan dalam pengimplementasian fungsi-fungsi manajemen di lembaganya, maka untuk menjamin hal tersebut berjalan secara efektif, maka pelaksanaan pengendalian harus dapat melibatkan pihak bawahan/staf dan para guru untuk memberi pelaporan pertanggungjawaban secara rutin kepada pimpinan. Hal tersebut juga akan memberikan jaminan terhadap mutu pendidikan yang secara terus-menerus dilakukan.

Pengendalian dalam bentuk pengawasan terdiri dari; Pertama, pengawasan melekat. Pengawasan melekat berfungsi sebagai pengendai aktivitas kerja dalam sebuah lembaga yang bersifat terus-menerus yang dilakukan secara preventif dan represif agar para bawahan bekerja sesuai arahan dan dilaksanakan secara efektif dan efisien (Usman, 2014: 536-538). Dalam konteks ini dilakukan langsung oleh pimpinan atau direktur sebuah lembaga. Secara aturan hal ini mengacu pada Instruksi Presiden Nomor 15 Tahun 1983 Tentang Pedoman Pengawasan Melekat (Usman, 2014: 537).

Kedua, pengawasan fungsional. Pengawasan fungsional adalah pengawas yang diberi mandat dan wewenang oleh pemerintah untuk melakukan audit secara menyeluruh terhadap aktivitas lini kerja yang terdapat dalam sebuah lembaga. Tugas pokok aparat pengawasan fungsional ini berupa survei, pengauditan, pemeriksaan, verifikasi dan pemantauan. Secara spesifik pengawasan fungsional dibagi dua yaitu pengawas internal dan pengawas eksternal. Pengawas internal adalah seseorang yang ditunjuk untuk melakukan tugas pengawasan di internal lembaga yang bertujuan untuk memberi petunjuk terhadap kesalahan atau inefisiensi terhadap kesalahan sistem dan program. Seingga ia lebih difungsikan sebagai konsultan manajemen Lembaga. Sementara pengawasan eksternal lebih dikedepankan untuk membangun semangat kemitraan (partnership) antara pengawas dengan yang diawasi. Namun pengawasan eksternal dilakukan secara berkala (Usman, 2014: 538).

Berdasarkan uraian di atas, dalam konteks ini dapat diketengahkan bahwa bentuk pengendalian yang dapat dilakukan oleh pimpinan madrasah terhadap aktivitas kerja dan proses pembelajaran di madrasahnya agar mutu Pendidikan dapat ditingkatkan yaitu: 
1. Pemimpin memonitoring seluruh aktivitas kelembagaan yang mengarah pada peningkatan mutu yang didasarkan pada perencanaan strategis;

2. Pemimpin memiliki informasi terkait hasil kinerja para bawahan atau kelembagaan yang berhasil mencapai tahap-tahap strategis yang telah ditetapkan;

3. Pemimpin memiliki standar dalam hal kinerja kelembagaan yang mengacu pada standar mutu Pendidikan.

Berangkat dari teori di atas, maka strategi dan pengendalian dalam proses peningkatan mutu pendidikan, dasarnya adalah tindakan yang terencana, sistematis, terukur dan terkendali dalam mencapai tujuan yang diharapkan. Hal ini mengisyaratkan bahwa tindakan strategis dan pengendalian kepemimpinan dalam meningkatkan mutu pendidikan berhasil ialah dengan adanya pelibatan seluruh komponen pendidikan (civitas akademika) dalam sebuah lembaga, mulai dari jajaran pimpinan (kepala madrasah dan wakilnya), guru, staf/pegawai (tenaga kependidikan), peserta didik, serta para stakeholders pendidikan. Sehingga kepala sekolah/madrasah dalam hal ini menempati posisi yang strategis dan penting dalam upaya merumuskan tindakan stratgeis sekaligus mengendalikan seluruh aktivitas kelembagaan dan kinerja para bawahannya dalam mencapai tujuan-tujuan yang telah ditetapkan dalam rangka meningkatkan mutu pendidikan.

\section{Peran Pemimpin dalam Meningkatkan Mutu Pendidikan}

Faktor penting yang besar pengaruhnya tehadap mutu pendidikan adalah kepala madrasah/sekolah sebagai pemimpin pendidikan. Kepala madrasah di sini memiliki tanggung jawab untuk memantau dan mengorganisir seluruh bawahannya dalam proses melaksanakan program Pendidikan yang dilaksanakan dalam mencapai visi-misi dan tujuan madrasah.

Manajemen dalam aktivitasnya mensyaratkan bahwa seorang pemimpin berperan sebagai pengelola. Dilihat dari fungsi-fungsi manajemen, planning, organizing, actuating, controlling, maka kepala madrasah/sekolah harus berperan pula sebagai supervisor pengajaran serta sebagai evaluator program madrasah (Mulyasa, 2012: 181). Pimpinan madrasah dituntut untuk mampu memimpin sekaligus mengorganisir dan mengelola pelaksanaan program belajar mengajar yang diselenggarakan di madrasah yang dipimpinnya. Dalam hal ini, kepala madrasah harus mampu menjadi supervisor tim yang terdiri dari guru, staf, dan siswa dalam mewujudkan proses belajar mengajar yang efektif dan efisien sehingga tercapai produktivitas belajar yang pada akhirnya dapat 
meningkatkan mutu pendidikan (Mulyasa, 2012: 181). Di samping sebagai supervisor, kepala madrasah juga harus mampu menjadi evaluator bagi program-program yang telah dilaksanakan. Semua pelaksanaan dari rencana kerja yang telah terwujud secara berkala harus dievaluasi. Evaluasi diperlukan agar penyimpangan-penyimpangan bisa dihindarkan serta untuk menjamin tercapainya tujuan (Mulyasa, 2012: 181).

Lebih lanjut Mulyasa (2012: 182) menerangkan, evaluasi yang dilakukan oleh kepala sekolah hendaknya lebih banyak berhubungan dengan pelaksanaan kurikulum dengan mengacu pada proses belajar mengajar yang produktif. Evaluasi yang dilakukan juga merupakan fungsi pengawasan (controlling) terhadap jalannya organisasi sekolah dan dewan sekolah dalam rangka menjaga mutu pelaksanaan program. Hasil dari evaluasi ini selanjutnya dapat dijadikan sebagai bahan untuk perbaikan-perbaikan yang diperlukan.

Berdasarkan penjelasan di atas, maka kepala madrasah dalam rangka meningkatkan mutu Pendidikan di madrasahnya lebih bertumpu pada perannya dalam menjalankan tugas dan aktivitas di madrasah. Pemimpim dalam hal tersebut harus terlibat langsung dalam mengelola, mengawasi, dan mengevaluasi semua aktivitas yang berlangsung dalam proses pembelajaran di madrasah. Tujuannya agar semua rencana dan tujuan yang ingin dicapai madrasah dapat dijalankan secara baik dan produktif.

\section{METODE PENELITIAN}

Penelitian ini dilakukan berdasarkan kajian lapangan, lokus penelitian dilakukan di Madrasah Aliyah Negeri (MAN 1 Yogyakarta). Fokus penelitian membahas tentang strategi dan pengendalian kepemimpinan sebagai upaya dalam meningkatkan mutu Pendidikan di MAN 1 Yogyakarta. Jenis penelitian ini adalah deskriptif kualitatif yaitu penelitian yang berupaya untuk menggambarkan, menjelaskan fenomena-fenomena yang terjadi secara alamiah di lapangan sekaligus menjawab persoalan yang muncul dari fenomena tersebut (Moleong, 2010: 3). Metode pengumpulan data dilakukan dengan observasi non partisipan, wawancara mendalam dan telaah dokumentasi. Subjek dalam penelitian ini yaitu Waka bagian kurikulum dan beberapa guru. Sementara yang menjadi objek pengamatan adalah proses dan mutu pendidikan yang sedang berlangsung di MAN 1 Yogyakarta. 


\section{HASIL DAN PEMBAHASAN}

\section{Langkah Strategis MAN 1 dalam Meningkatkan Mutu Pendidikan}

1. Pelatihan dan Pengembangan Guru

Kepala MAN 1 Yogyakarta mengambil langkah strategis dalam proses peningkatan mutu Pendidikan di madrasahnya ialah dengan melakukan perencanaanperencanaan strategis. Dalam rangka mempersiapkan guru dan tenaga didik yang berkualitas, pimpinan pertama sekali fokus terhadap kegiatan pelatihan dan pengembangan para guru dan tenaga kependidikan lainnya (Giyono dalam wawancara: 2017). Pelatihan sebagai salah satu cara pengembangan kualitas proses belajarmengajar juga dipertegas oleh Agustinus Hermino (2013:91) bahwa pelatihan sangat dibutuhkan untuk meningkatkan keterampilan kerja.

Program pelatihan yang diselenggarakan oleh pihak madrasah melalui workshop pelatihan dan ditambah dengan kegiatan outbond. Dalam pelaksanaan pelatihan ini, pihak madrasah melakukan kerja sama dengan Balai Pendidikan dan Pelatihan (Diklat), Lembaga Penjaminan Mutu Pendidikan (LPMP) serta melibatkan badan pengawas madrasah dalam melakukan pembimbingan (Giyono dalam wawancara: 2017). Senada dengan ini Imam Machali dan Ara Hidayat (2016:174) juga memandang bahwa membangun kerja sama ke berbagai pihak terkait penting dalam meningkatkan mutu sebuah lembaga Pendidikan. Hal ini dapat dipahami karena sumber daya di dalam madrasah juga memiliki keterbatasan.

Demi kesuksesan dan kelancaran pelaksanaan program pelatihan dan pengembangan, pimpinan madrasah sebelumnya melakukan rapat dengan para bawahan dalam merumuskan kegiatan yang akan dilaksanakan dengan tujuan agar program yang dilaksanakan dapat berjalan mencapai target dan sasarannya. Di samping itu agar anggaran yang telah ditetapkan dapat digunakan secara efisien (Giyono dalam wawancara: 2017).

Sebagaimana diketahui bahwa kualitas guru dalam mengajar sangat bertemali dengan prestasi siswa. Pentingnya pelatihan terhadap proses pembelajaran yang dilaksanakan di madrasah ini juga menjadi tantangan tersendiri bagi setiap madrasah yang ada di Indonesia. Menurut Trends in Mathematic and Science Study (TIMSS) 2003-2004, siswa Indonesia hanya berada di ranking ke-35 dari 44 negara dalam hal prestasi matematika dan ranking ke-37 dari 44 negara dalam hal prestasi sains. Dalam hal ini prestasi siswa Indonesia jauh di bawah siswa Malaysia dan Singapura sebagai 
Negara tetangga yang terdekat (Musfah, 2015: 52). Political and Economic Risk Consultant (PERC) melaporkan bahwa kualitas pendidikan di Indonesia berada pada posisi ke-12 dari 12 negara di Asia. Sementara itu data The World Economic Forum Swedia (2000) menyatakan bahwa daya saing Indonesia rendah hanya berada pada ranking ke 37 dari 57 negara di dunia ini yang disurvei (lihat https://www.unsur.ac.id/berita-907/Ada-Apa-dengan-Pendidikan-di-Indonesia).

Berdasarkan laporan di atas, MAN 1 Yogyakarta sebagai lembaga pendidikan Islam berpredikat unggul, mengambil langkah strategis dengan cara memprioritaskan kualitas proses pembelajaran yang diterapkan di kelas melalui pengembangan program pelatihan-pelatihan baik terhadap guru maupun siswa. Namun demikian data di lapangan menunjukkan bahwa program pelatihan masih bertumpu pada perencanaan waktu awal tahun semester. Sehingga inovasi dan pengembangan serta tindak lanjut pelatihan guru dan siswa tampak masih kurang diperhatikan (Dzulhaq Nurhadi dalam wawancara: 2017). Sementara hal tersebut menjadi salah satu output yang diharapkan dari diadakannya kegiatan pelatihan.

2. Pengembangan Proses Pembelajaran Siswa

Langkah strategis yang diambil pimpinan madrasah dalam upaya meningkatkan mutu proses pembelajaran terhadap siswa adalah dengan mengambil kebijakan yaitu memprioritaskan program pembelajaran yang diklasifikasikan pada tiga ranah kajian, pertama bidang akademik, kedua, bidang tahfidz, dan ketiga bidang riset. Di samping itu ada pendalaman program try out yang secara terus menerus dilakukan (Nur Fathurahman Ridwan dalam wawancara: 2017)

Kegiatan pada bidang akademik yang dilakukan pihak MAN 1 terhadap para siswa yaitu dengan mengundang secara berkala para akademisi kampus yang berada di sekitar kota Yogyakarta dari berbagai lintas keilmuan untuk mengisi semacam seminar di madrasah dengan tujuan memberikan penerangan keilmuan terhadap para siswa (Nur Fathurahman Ridwan dalam wawancara: 2017). Dari kegiatan semacam itu pikiran para siswa dibuka dan diperkenalkan dengan penemuan-penemuan baru dari sebuah penelitian atau kajian. Sehingga suasana akademik di kalangan siswa terbangun dan para siswa terdorong untuk mengetahui banyak hal dari apa yang mereka dengar.

Strategi yang dapat dikatakan menjadi keunggulan tersendiri dari MAN 1 Yogyakarta ini adalah bahwa pihak madrasah sangat konsen terhadap pendampingan 
siswa. Siswa terlihat diberikan arahan dan bimbingan khusus secara berkelompok sesuai dengan bakat dan minat yang mereka miliki masing-masing oleh guru yang ditunjuk langsung dalam proses pengarahan dan pembimbingan tersebut. Hal semacam ini sesungguhnya adalah orientasi yang penting untuk dicapai oleh setiap sekolah. Dimana peserta didik menemukan potensi yang terpendam dalam diri mereka masingmasing sehingga dengan adanya arahan dan bimbingan mereka mampu mengembangkan dan mengaktualisasikannya dalam kehidupan nyata.

Dalam bidang tahfidz al-Qur'an, pihak madrasah mengambil langkah strategis dengan cara menghadirkan secara khusus para ustaz/ustazah yang hafal al-Quran untuk memberikan pembinaan dan bimbingan kepada para siswa. Proses awal yang dilakukan oleh para Pembina dalam bidang tahfidz ini adalah dengan memasuki setiap kelas untuk "menggaet" dan memetakan potensi calon pen-tahfidz di kalangan siswa. Proses selanjutnya yaitu membina secara khusus di luar kelas (Giyono dalam wawancara: 2017).

Salah satu unsur penunjang terhadap program tahfidz yang dijalankan di MAN 1 Yogyakarta ialah bahwa para siswa yang mengikuti program tahfidz harus tinggal di asrama madrasah. Sehingga mereka dengan mudah dapat dibina dengan baik. Dengan demikian indikator terhadap berhasilnya madrasah mengeluarkan peserta didik yang hafal Al-qur'an tidak lepas dari peran asrama yang diadakan madrasah.

Selanjutnya adalah riset. Langkah strategis dalam meningkatkan program riset ini diambil pihak pimpinan madrasah dengan mengadakan secara khusus guru yang membidani masalah riset di kalangan siswa. Program riset menjadi salah satu unggulan dari MAN 1 Yogyakarta. Sehingga tidak heran bila salah satu peroleh penghargaan terbanyak yang diraih pihak madrasah adalah melalui program risetnya.

Langkah-langkah strategis yang diambil pihak pimpinan dalam peningkatan program riset ini yaitu; pertama, mengadakan guru khusus yang membimbing secara intensif kegiatan riset siswa, kedua, kerjasama madrasah dengan perguruan tinggi dalam penggunaan laboratorium tempat siswa menguji-cobakan temuan risetnya, ketiga, memberikan insentif secara langsung kepada para siswa yang sedang malakukan riset di lapangan.

Strategi pembimbingan yang diterapkan oleh pimpinan madrasah di atas, telah dapat memberikan kontribusi secara signifikan terhadap citra dan nama baik madrasah di mata masyarakat. Hal ini dapat dimaklumi karena dengan diterapkannya strategi 
dalam perekrutan siswa yang masuk di madrasah itu sendiri. Di mana pihak madrasah mampu mendapatkan siswa melalui jalur prestasi, dan sejak awal para siswa telah berprestasi pada jenjang pendidikan sebelumnya. Hal ini berdasarkan keterangan yang disampaikan pimpinan madrasah bahwa sebagai madrasah unggul, pihak madrasah telah diberikan kesempatan yang luas untuk menerima siswa berprestasi.

Adapun faktor penunjang lain yang turut memberikan dukungan terhadap prestasi siswa di MAN 1 Yogyakarta adalah pada penerapan kurikulum yang berbasis minat dan bakat siswa. Kurikulum sebagai acuan dalam memberikan pengajaran dan proses pembelajaran terus-menerus menjadikan siswa dapat melangsungkan proses pembelajaran secara baik dan mudah memahami materi yang diajarkan. Di samping itu para guru yang tersedia didorong untuk melakukan strategi tersendiri dalam melakukan proses pembelajaran di dalam kelas: melalui metode diskusi, penugasan kelompok dengan pembahasan tema-tema yang berhubungan langsung dengan kondisi di masyarakat.

\section{Pengendalian Kepemimpinan MAN 1 Yogyakarta}

Merujuk pada Peraturan Menteri Pendidikan Nasional Republik Indonesia Nomor 13 Tahun 2007, tentang standar Kepala Madrasah/Sekolah, dijabarkan dalam salah satu dimensi kompetensi kepribadiannya, disebutkan bahwa kepala sekolah/madrasah harus dapat mengendalikan diri dalam menghadapi masalah dalam pekerjaan sebagai kepala sekolah/madrasah, dan menciptakan budaya dan iklim madrasah/sekolah yang kondusif dan inovatif bagi pembelajaran peserta didik (Permendiknas Nomor 13 Tahun 2007).

Pengendalian kerja yang dilaksanakan oleh kepala MAN 1 Yogyakarta untuk menjamin berjalannya seluruh aktivitas kerja di madrasah sesuai dengan rencana yang diinginkan yaitu; (Giyono dalam wawancara: 2017) pertama, mererapkan pola hubungan demokratis antara pimpinan dengan bahawan. Pola ini dilakukan dengan bentuk pendistribusian tugas dan tanggungjawab sepenuhnya terkait dengan program yang langsung dibawahi oleh masing-masing bidang yang ada dalam struktur kerja di madrasah. Seperti kegiatan belajar mengajar (KBM) pertanggung jawabannya langsung diserahkan kepada para guru yang bersangkutan. Hubungan madrasah dengan pihak luar atau stakeholders diserahkan sepenuhnya kepada bidang Hubungan Masyarakat (Humas). Yang berhubungan dengan kegiatan ekstrakurikuler kesiswaan, pertanggung jawabannya langsung diserahkan kepada para siswa itu sendiri. Dari seluruh aktivitas tersebut pada akhirnya pimpinan menerima laporan secara tertulis. 
Kedua, pimpinan madrasah memberikan peran dengan pola komando langsung kepada para bawahan bila terdapat hal-hal penting yang harus dilaksanakan pada lini kerja di bawahnya. Hal ini dilakukan agar teknis pelaksanaan kerja yang penting tidak menyimpang dari tujuan madrasah. Peran pimpinan dalam bentuk komando ini tampak sebagai bentuk pengambilan keputusan (decision maker) inti dalam sebuah unit lembaga (lihat Tilaar dan Riant Nugroho, 2009:430). Sementara itu hubungan koordinasi dengan bawahan selalu mengutamakan pendekatan dialogis, hal tersebut dilakukan dengan terusmenerus, simultan dan membaur dalam aktivitas pembelajaran di madrasah. Sehingga antara pimpinan dan bawahan tampak tidak ada sekat-sekat yang hierarkis. Berbeda halnya seperti yang dirumuskan oleh T. Hani Handoko (2015:196) misalnya yang menyebutkan bahwa pendekatan untuk pencapaian koordinasi efektif salah satunya dilakukan dengan pendekatan hierarki manajerial.

Peran lain yang dilakukan pimpinan dalam mengendalikan proses pembelajaran agar terbangun nuansa religious yaitu dengan menerapkan shalat dhuha secara berjamaah lima belas menit sebelum mata pelajaran dimulai dan dilakukan secara bergiliran (Giyono dalam wawancara: 2017). Sementara pada giliran lain membaca Al-qur'an dan Asma'ul Husna. Hal tersebut dilakukan dalam rangka merekayasa dan menciptakan lingkungan yang agamais dan kondusif agar para civitas akademika di madrasah dapat melakukan proses pembelajaran yang memiliki dimensi penghayatan agama (Budiyanto, 2009:168). Sementara hal yang berhubungan langsung dengan penilaian kinerja madrasah secara keseluruhan, seluruhnya menjadi kewenangan pengawas sekolah yang telah ditunjuk secara resmi.

Berdasarkan keterangan yang disampaikan Taufik Zamhari (dalam wawancara: 2017), bentuk pengawasan yang selama ini dilaksanakan di madrasah dalam proses pembelajaran ialah langsung melihat dan menilai bagaimana guru dalam mempraktekkan cara belajar dan cara memberikan materi ajar terhadap siswa di dalam kelas. Adapun pengawas yang terlibat dalam struktur internal madrasah adalah kepala madrasah dan beberapa guru yang dipilih langsung. Lebih lanjut wakil kepala madrasah menjelaskan, bahwa seluruh aktivitas kerja yang dilaksanakan oleh para bawahan termasuk para guru yang menjalankan kegiatan belajar mengajar di kelas, pada umumnya dapat dijalankan dengan baik dan tidak ada kendala yang cukup berarti dalam pelaksanaannya.

Sebagai bentuk tindakan preventif yang dilakukan pihak madrasah untuk mengendalikan munculnya masalah besar dari para siswa yang melakukan kesalahan 
yaitu dengan langsung memanggil orang tua siswa yang bersangkutan. Kesalahankesalahan seperti merokok, tidak mengerjakan tugas, mengabaikan arahan guru dan absen pada saat proses pembelajaran merupakan hal yang harus segera diatasi secara langsung agar tidak terulang dan menyebar ke siswa lain. Sehingga upaya pemanggilan orang tua atau wali murid secara langsung menjadi pengendalian jitu dari pihak madrasah. Pada sisi lain pemanggilan orang tua siswa atas masalah yang dihadapi oleh siswa merupakan upaya tersendiri untuk melibatkan orang tua secara langsung dalam memantau perkembangan proses belajar siswa di madrasah (Munirwan Umar, 2015:20).

Namun jika mengacu pada model ideal yang harus dijalankan pada manajemen madrasah, adalah harus adanya timbal balik antara kinerja saat ini dengan hasil yang diharapkan. Hal ini berarti perlu adanya evaluasi terus menerus kepada para bawahan yang melaksanakan aktivitas pendampingan peserta didik. Sehingga peningkatan mutu pendidikan dapat diperluas cakupannya kepada hal yang lebih luas.

Seluruh proses dan langkah strategis yang diiringi dengan tindakan pengendalian yang dilakukan oleh pimpinan MAN 1 Yogyakarta di atas tampak bahwa strategi dan pengendalian yang diterapkan tetap mengandalkan pihak luar sebagai pihak yang berkaitan langsung dengan Pendidikan. Mutu Pendidikan dipandang sebagai faktor penting dan esensial dalam meraih prestasi dan keunggulan program yang dijalankan. Peran dan keterlibatan seluruh warga madrasah terus ditekankan untuk secara bersamasama meraih prestasi unggul seiring dengan strategi dan pengendalian yang dijalankan madrasah. Sehingga dalam prakteknya dinamisasi proses pelaksanaan strategi dan pengendalian dalam meningkatkan mutu Pendidikan menjadi kata kunci dalam sebuah proses kepemimpinan di madrasah.

\section{KESIMPULAN}

Berdasarkan pembahasan dan analisis atas penelitian di atas, secara umum mutu Pendidikan di MAN 1 Yogyakarta berhasil ditingkatkan melalui strategi dan pengendalian yang dilakukan pihak pimpinan madrasah. Strategi yang diterapkan di MAN 1 Yogyakarta secara teknis telah dilakukan berdasarkan langkah-langkah strategis yang jitu dengan memanfaatkan peluang yang ada di sekitar madrasah. Adapun bidang yang diprioritaskan dalam strategi kepala madrasah di sini adalah pertama, pengembangan dan pelatihan bagi para guru dengan mengadakan program pelatihan kualitas pengajaran secara periodik. Kedua, peningkatan proses pembelajaran peserta 
didik di luar proses belajar mengajar di dalam kelas yaitu bidang akademis, tahfidz, dan riset. Bidang akademis dengan melakukan pertemuan ilmiah secara berkala dengan mengundang para akademisi kampus. Bidang tahfidz ditingkatkan dengan pendampingan secara intens di asrama madrasah. Bidang riset ditingkatkan dengan cara menugaskan guru-guru khusus yang secara instens membimbing dan mengarahkan para siswa untuk melakukan kegiatan penelitian.

Pengendalian yang diterapkan pimpinan madrasah untuk menjamin berjalannya kinerja madrasah yaitu pertama, dengan pendekatan demokratis yang ditandai dengan pendistribusian tugas dan tanggung jawab kerja ke masing-masing bidang, kedua, mengambil peran pada setiap lini kerja dengan mengambil keputusan langsung bila ditemui hambatan, serta mengutaman koordinasi dengan pendekatan yang dialogis terhadap bawahan. Dalam menjamin proses pembelajaran agar berjalan sesuai dengan tujuan madrasah dilakukan penciptaan suasana religious dengan membiasakan salat duha, berdzikir dan membaca Al-Qur'an bagi warga madrasah. Sementara tindakan preventif yang dilakukan pihak madrasah dalam mengawasi perilaku siswa yang bermasalah yaitu dengan memanggil orang tua atau wali murid secara langsung dengan tujuan agar terulang kesalahan yang sama dan orang dapat dilibatkan secara langsung dalam proses pembelajaran siswa di madrasah.

\section{DAFTAR PUSTAKA}

Ace, Suryadi; dkk. (2014). Pendidikan Untuk Transformasi Bangsa. Jakarta: PT Kompas Media Nusantara.

Baswedan, A. R. (2015). Kepemimpinan Kepala Sekolah \& Kepuasan Kerja Guru (H. Soekirman (ed.)). Medan: Taman Bacaan Masyarakat Pujakesuma.

Budiyanto, D. (2009). Prophetic Learning Menjadi Cerdas dengan Jalan Kenabian. Yogyakarta: Pro-U Media.

Hadi, S., \& Novaliyosi. (2019). TIMSS Indonesia (Trends in International Mathematics and Science Study). Prosiding Seminar Nasional \& Call For Papers Program Studi Magister Pendidikan Matematika Universitas Siliwangi, 562-569.

Handoko, T. H. (2015). Manajemen (2nd ed.). Yogyakarta: BPFE-Yogyakarta.

Hermino, A. (2013). Asesmen Kebutuhan Organisasi Persekolahan Tinjauan Perilaku Organisasi Menuju Comprehensive Multilevel Planning. Jakarta: PT Gramedia Pustaka Utama.

Hidayat, I. M. A. (2016). The Handbook Of Education Management Teori Dan Praktik Pengelolaan Sekolah/Madrasah Di Indonesia. Jakarta: Prenadamedia Group. 
Moleong, L. J. (2010). Metodologi Penelitian Kualitatif. Bandung: PT Remaja Rosdakarya.

Mulyasa, H. E. (2012). Manajemen dan Kepemimpinan Kepala Sekolah. Jakarta: Bumi Aksara.

Musfah, J. (2015). Manajemen Pendidikan Teori, Kebijakan, dan Praktik. Jakarta: Prenada Media Group.

Na'im, Z. (2019). Relevansi Teknologi Pendidikan dan Mutu Pendidikan. Evaluasi, 1(1), $1-30$.

http://e-journal.staima-alhikam.ac.id/index.php/evaluasi/article/view/296/pdf

H.A.R. Tilaar, R. N. (2009). Kebijakan Pendidikan: Pengantar untuk Memahami Kebijakan Pendidikan dan Kebijakan Pendidikan sebagai Kebijakan Publik. Yogyakarta: Pustaka Pelajar.

Peraturan Menteri Pendidikan Nasional Republik Indonesia. (2007). Peraturan Menteri Pendidikan Nasional Republik Indonesia Nomor 13 Tahun 2007 tentang Standar Kepala Sekolah/Madrasah. Jakarta: Sekretariat Negara.

Sagala, S. (2013). Manajemen Strategik dalam Peningkatan Mutu Pendidikan: Pembuka Ruang Kreativitas, Inovasi dan Pemberdayaan Potensi sekolah dalam Sistem Otonomi Sekolah. Bandung: Alfabeta.

Sirojuddin, A. (2020). Pengaruh budaya supervisi kepala sekolah terhadap peningkatan profesionalisme guru. Nidhomul Haq: Jurnal Manajemen Pendidikan Islam, 5(1), 119-140. https://doi.org/10.31538/ndh.v5i1.589. 119-140

Umar, M. (2015). Peranan Orang Tua Dalam Peningkatan Prestasi Belajar Anak. In JURNAL EDUKASI: Jurnal Bimbingan Konseling , 1(1), 20-28. https://doi.org/10.22373/je.v1i1.315, 20-28

Usman, H. (2014). Manajemen: Teori, Praktik dan Riset Pendidikan (4th ed.). Jakarta: PT Bumi Aksara.

Wahyudi. (2009). Kepemimpinan Kepala Sekolah dalam Organisasi Pembelajar: Learning Organization. Bandung: Alfabeta.

WWW.compas.com, Kompetisi Sains Madrasah Membongkar Stigma Kelas Dua, ditayangkan oleh Y. E. Harususilo, pada Rabu 18 September 2019 dan diakses 28 Februari 2020.

WWW.unsur.ac.id. Ada Apa dengan Pendidikan di Indonesia?, ditayangkan oleh Tim Universitas Suryakancana pada 22 Maret 2018, diakses 16 Maret 2020.

WWW.manyogya1.sch.id. Sejarah MAN Yogyakarta I, ditayangkan oleh Humas MAN 1 Yogyakarta pada 21 November 2016, dan diakses pada 23 Desember 2017. 